\title{
ŠLAPIMO ORGANŲ INFEKCIJA KARDIOLOGINIO PROFILIO INTENSYVIOS TERAPIJOS SKYRIUJE
}

\author{
Dalia Adukauskienė $\dot{1}^{1}$ Tadas Kaučikas ${ }^{2}$, Agnė Adukauskaite் ${ }^{3}$, Romualdas Mačiulaitis ${ }^{4,5}$, \\ Inga Skarupskiené $\dot{e}^{4}$, Daiva Pentiokiniene் $\dot{e}^{3}$, Giedrè Stanaitiené $\dot{e}^{3}$
}
${ }^{1}$ Lietuvos sveikatos mokslu universiteto Medicinos akademijos Intensyviosios terapijos klinika, ${ }^{2}$ Anesteziologijos klinika, ${ }^{3}$ Kardiologijos klinika, ${ }^{4}$ Nefrologijos klinika, ${ }^{5}$ Fiziologijos ir farmakologijos institutas

Raktažodžiai: šlapimo organų infekcija, rizikos veiksniai, antimikrobinis gydymas, mirštamumas.

\begin{abstract}
Santrauka
Darbo tikslas. Nustatyti Kardiologijos intensyvios terapijos skyriaus (KITS) pacientų šlapimo organų infekcijos (ŠOI) rizikos veiksnius, sukèlejus, antimikrobini gydymą, ŠOI gydymo bei hospitalizacijos KITS trukmę, mirštamumą ir jo rizikos veiksnius.

Metodai. I retrospektyvaus tyrimo imti įtraukti 57 pacientai, 2007-2011 m. gydyti Kauno kliniku KITS, kuriems buvo nustatyta bakteriurija.

Rezultatai. Vyrų ir moterų bakteriurijos dažnis nesiskyrè (47,4 proc. ir 52,5 proc.). Tiriamujų vidutinis amžius $73,01 \pm 12,3 \mathrm{~m}$., bakteriurija dažniau nustatyta pacientams $>65 \mathrm{~m}$., lyginant su jaunesniais, $\mathrm{p}<0,05$. ŠOI sirgo 52 iš 57 tiriamųų. Visiems 11 cukriniu diabetu (CD) sirgusių pacientų išsivyste ŠOI. Šlapimo pūslès kateterizacija taikyta 49 pacientams, iš jų 45 sirgo ŠOI. Vidutinè tirtų KITS pacientų kateterizacijos trukmé $10 \pm 2$ d. Dažniausiai ŠOI sukèlè gramneigiama lazdelè - 44 atvejai iš 64, iš jų E. coli - 43,2 proc. $(p<0,05)$, grybai išauginti kritinių būklių, ilgiau gydytiems pacientams. Dažniausiai skirtas antibiotikas (AB) - cefuroksimas (77 proc.). Pacientams, kuriems empirinis antibakterinis gydymas buvo adekvatus $(\mathrm{n}=24,46$ proc.), ŠOI trukmė 9,9 $9 \pm 4,7$ d., kai neadekvatus (dažniausiai

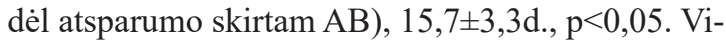
dutinè hospitalizacijos KITS trukmé kolonizacijos

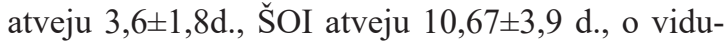
tine tirto laikotarpio hospitalizacijos KITS trukmè $1,08 \pm 0,4$ d., $\mathbf{p}<0,05$. Grybo sukeltos ŠOI atveju hos-
\end{abstract}

pitalizacijos KITS trukmè $27,75 \pm 12,3$ d., o bakterijų 10,68 $\pm 5,3$ d., $p<0,05$. Kai empiriškai paskirtas antibakterinis gydymas buvo adekvatus, gydymo KITS trukmė buvo 3,3 $\pm 2,1$ d., o kai neadekvatus $14,7 \pm 5,3 \mathrm{~d}$., $\mathrm{p}<0,05$. Vyresnis nei $50 \mathrm{~m}$. amžius, $C D$ (95 proc., ŠS 1,3, PI 0,33 - 4,99), šlapimo pūslès kateterizacija ir jos trukmè (visi mirę pacientai buvo kateterizuoti, ir mire 76 proc., kuriems taikyta ilgalaikè kateterizacija) susieta su mirštamumu, $\mathrm{p}<0,05$. Išvados. Bakteriurija būdinga $>65 \mathrm{~m}$. amžiaus pacientams. Beveik visuomet ji susijusi su šlapimo organų infekcija, jos reikšmingi rizikos veiksniai - cukrinis diabetas ir šlapimo pūslès kateterizacija. Du trečdaliai šlapimo organų infekcijos sukèlëjų gramneigiamos lazdelès, iš jų pusè - E. coli. Dažniausiai empiriškai šlapimo organų infekcija gydyta intraveniniu cefuroksimu. Empirinis antibakterinis gydymas adekvatus buvo mažiau nei pusei atvejų, dažniausia gydymo neadekvatumo priežastis - sukèlèjo atsparumas skirtam antibiotikui. Tiek šlapimo organų infekcija, tiek ir šlapimo kolonizacija mikrobais didino hospitalizacijos KITS trukmę. Hospitalizacijos KITS trukmė mažesnè, kai šlapimo organų infekcijos sukèlèjas E. coli, didžiausia, kai grybas. Adekvataus antibakterinio gydymo atveju tiek šlapimo organų infekcijos gydymo trukmè, tiek ir hospitalizacijos KITS trukmè ženkliai mažesnè. KITS pacientų, sergančių šlapimo organų infekcija, mirštamumas 40 procentų. Jị didino vyresnis nei 50 m. amžius, cukrinis diabetas bei šlapimo pūslès kateterizacija, ypač - ilgalaikè.

Ivadas

Šlapimo organų infekcija - tai patogeninių mikroor- 
ganizmų nustatymas šlapimo pasèlyje, kartu esant ir klinikiniams bei laboratoriniams uroinfekcijos požymiams, o kolonizacija - kai pastarujų nenustatoma (1-3). ŠOI yra viena dažniausių hospitalinių infekcijų kritinių būklių pacientams (1-5). Skirtingų autorių duomenimis, apie 80 proc. šių infekcijų yra susiję su šlapimo pūslès kateterizacija, 10-20 proc. - su kitomis manipuliacijomis šlapimo organuose (1-3). Sunkios būklès pacientu gydymo intensyvios terapijos skyriuose (ITS) trukmè ir baigtys priklauso nuo ivvairių veiksnių, taip pat ir nuo ligonineje igytos ŠOI bei jos tinkamo gydymo, todèl racionalių šlapimo pūslès kateterizacijos indikacijų bei empirinès adekvačios antibiotikoterapijos parinkimas yra aktuali nūdienos medicinos problema $(2,6)$.

Šio tyrimo tikslas - nustatyti KITS pacientų ŠOI rizikos veiksnius, sukèlejus, antimikrobinị gydymą ir pradinio, t.y. empirinio gydymo adekvatumą, ŠOI gydymo bei hospitalizacijos KITS trukmę, mirštamumą ir jo rizikos veiksnius.

\section{Darbo objektas ir metodika}

I retrospektyvaus tyrimo imtị ịtraukti visi 57 pacientai, kurie 2007-2011 m. buvo gydyti kardiologinio profilio ITS skyriuje tretinio lygio ligonineje (Kauno klinikų KITS) ir kuriems buvo nustatyta bakteriurija iprastiniais ligonineje atliekamais mikrobiologinio tyrimo metodais. Tiriamuosius grupavome pagal: 1) demografinius duomenis, 2) bakteriurijos tipą - kolonizacija ar ŠOI (karščiavimas, leukocitozé, padideję̨s $\mathrm{C}$ reaktyvusis baltymas, leukociturija ir bakteriurija), 3) ŠOI rizikos veiksnius: CD, šlapimo pūslès kateterizacija - trumpalaikè (TK) $\leq 6$ parų ir ilgalaikè (IK) >6 paru, 4) sukèlèjus: gramneigiamos (Gneig) lazdelès, gramteigiami (Gteig) kokai, grybai, 5) empirinio antibakterinio gydymo adekvatumą, neadekvataus gydymo priežastis, 6) tyrème ŠOI ir kolonizacijos, sukèlèjų, antibiotikoterapijos neadekvatumo įtaką hospitalizacijos KITS trukmei, 7) mirštamumo rizikos veiksnius: lytis, amžius,

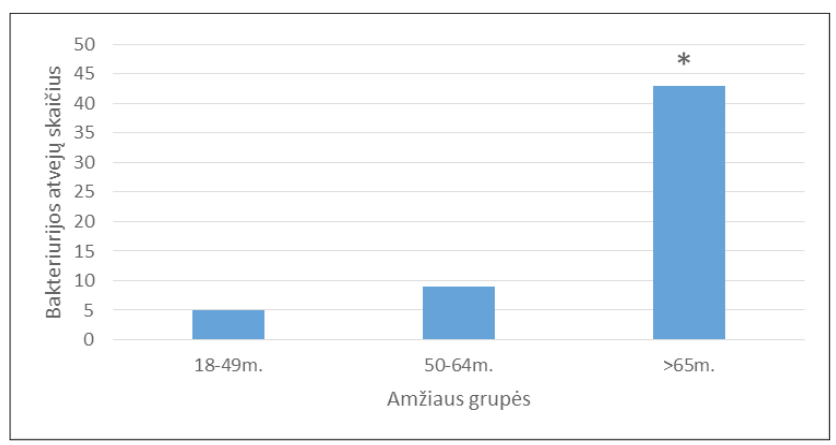

1 pav. Bakteriurija skirtingo amžiaus tiriamųjų grupèse ${ }^{*} p<0,05$
ŠOI sukèlèjas, CD, kateterizacija ir jos trukmè. Duomenų analizei naudota IBM SPSS Statistics 19 programa. Statistiniam analizuojamų kintamųų vidurkiu palyginimui taikytas Stjudent‘o (t) testas. Kategorinių požymių tarpusavio sąsajoms palyginti taikytas $\chi^{2}$ testas. Dviejų imčių, nepasiskirsčiusių pagal Gauso skirstini, palyginimui naudojome Mann-Whitney U testą. Rezultatai pateikiami kaip aritmetinis vidurkis plius/minus standartinè vidurkio paklaida $(\mathrm{M} \pm \mathrm{SE})$. Skirtumą laikème statistiškai reikšmingu, kai $\mathrm{p}<0,05$.

\section{Rezultatai}

Bakteriurija nustatyta $n=27$ (47,4 proc.) vyrams ir $n$ $=30$ (52,5 proc.) moterų. Bakteriurijos dažnis nepriklausè nuo tiriamujų lyties. Vidutinis pacientų amžius buvo $73,01 \pm 12,3 \mathrm{~m}$. Lyginant tarp skirtingų amžiaus grupių, bakteriurija reikšmingai dažniau nustatyta vyresniems nei $65 \mathrm{~m}$. pacientams $\mathrm{p}<0,05)(1 \mathrm{pav}$.).

Iš 57 bakteriurijos atvejų ŠOI sirgo $\mathrm{n}=52$ pacientai (91,2 proc.), kolonizacija nustatyta tik $\mathrm{n}=5$ (8,8 proc.), $\mathrm{p}<0,05$. ŠOI nustatyta 0,34 proc. visų KITS pacientu. ŠOI pasireiškè visiems sirgusiems $C D(n=11), p<0,05$. Šlapimo pūslès kateterizacija taikyta iš viso $n=49$ ( 86 proc.) pacientams su nustatyta bakteriurija. Po šlapimo pūslès kateterizacijos ŠOI buvo dažnesnè $n=45$ (91,8 proc.), nei šlapimo kolonizacija mikrobais $n=4, p<0,05$. Vidutinè tirtų KITS pacientų kateterizacijos trukmė $10 \pm 2 \mathrm{~d}$. ŠOI nustatyta 88 proc. $(n=28$ iš 32$)$, kuriems taikyta TK, ir visiems tiriamiesiems $(n=17)$, kuriems taikyta IK, $p<0,05$.

Vienas ŠOI sukèlèjas nustatytas - 41 atveju ( 78,8 proc.), du sukèlejjai - 11 (21,2 proc.). 44 iš 64 ŠOI sukèlusių mikroorganizmų (68,8 proc.) buvo Gneig lazdelès, Gteig lazdelè Corynebacterium spp. $n=2$ (3,1 proc.), Gteig kokai $n=14$ (21,9 proc.), grybai $n=4$ (6,3 proc.). Tarp Gneig sukèlejjų didžiausią dali sudare E. coli $\mathrm{n}=19$ (43,2 proc.), Klebsiella spp. $n=10$ (22,7 proc.), Pseudomonas spp. $n=9$ (20,5 proc.), Proteus spp. $n=5$ (11,4 proc.) ir Enterobacter spp.

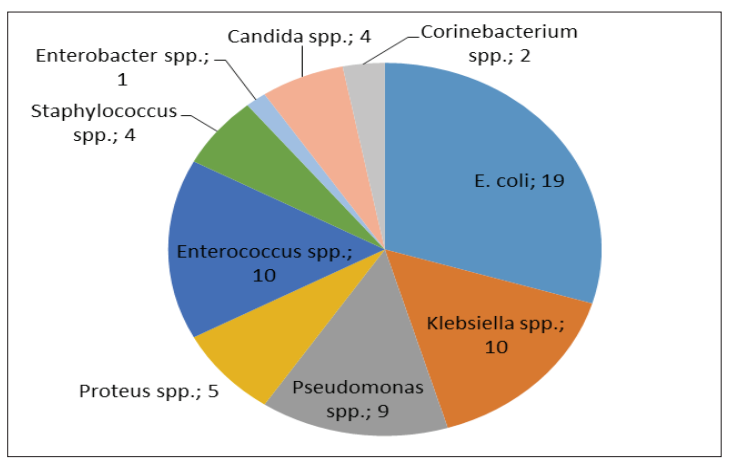

2 pav. Šlapimo organų infekcijų KITS sukèlèjai 
$\mathrm{n}=1$ (2,3 proc.). Gteig koku grupejje vyravo Enterococcus spp. $n=10$ (71,4 proc.), Staphylococcus spp. $n=4(28,6$ proc.). (2 pav.) Kolonizacijos atveju visada nustatytas vienas mikroorganizmas: E. coli $(\mathrm{n}=3)$, stafilokokai $(\mathrm{n}=2)$.

Intraveninis cefuroksimas skirtas $n=40$ (77 proc.) ŠOI atvejų, ampicilinas $n=5(9,6$ proc. $)$, ciprofloksacinas ir cefazolinas po $n=3$ (po 5,7 proc.), oksacilinas $n=1(1,9$ proc.). Empirinis antibakterinis gydymas adekvatus buvo 46,1 proc. ŠOI atvejų $(\mathrm{n}=24)$. Neadekvataus empirinio gydymo priežastys: 1) sukèlejjo atsparumas empiriškai paskirtam $A B$ $-\mathrm{n}=18$ atvejų (64,3 proc.), iš jų cefuroksimui $\mathrm{n}=11(39,3$ proc.), po $\mathrm{n}=3$ - ampicilinui ir cefazolinui (po 10,7 proc.), $\mathrm{n}=1$ - oksacilinui (3,5 proc.); 2) mišri flora, kai vienas sukèlèjų atsparus skirtam $\mathrm{AB} n=7$ ( 25 proc.), iš jų cefuroksimui $n=6$, ciprofloksacinui $n=1) ; 3$ ) per maža cefuroksimo dozè (vertinant pagal tai, kokia dozè rekomenduojama pagal preparato charakteristikų santrauką) $n=2(7,1$ proc.), 4) $A B$ neskirtas $n=1$ (3,5 proc.), (3 pav.). Esant ŠOI sukèlëjui grybui $(n=4)$, priešgrybinis gydymas neskirtas.

ŠOI trukmè $9,9 \pm 4,7$ d., kai empirinis gydymas buvo

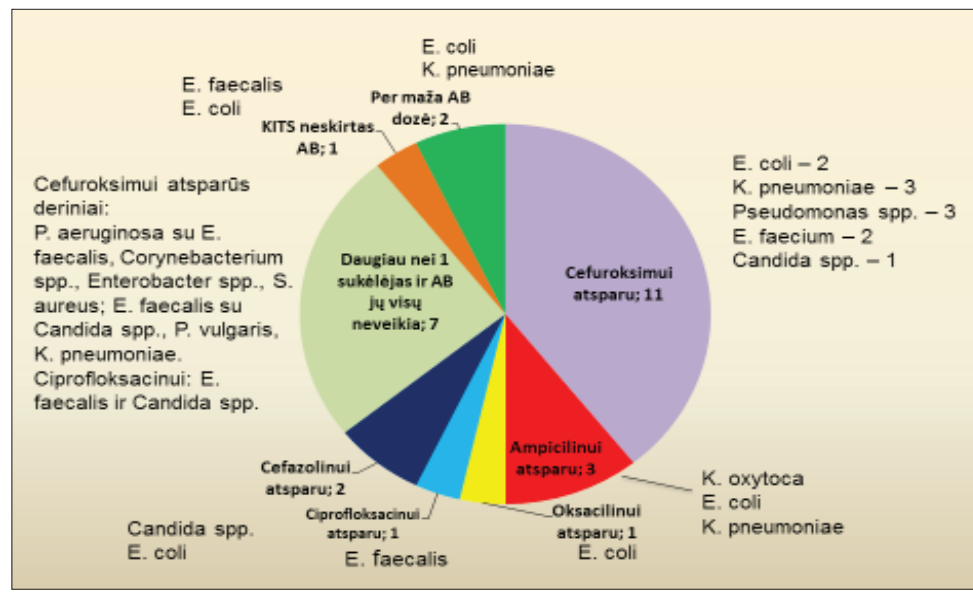

3 pav. Šlapimo organų infekcijų neadekvataus empirinio antimikrobinio gydymo mikrobiologinès priežastys

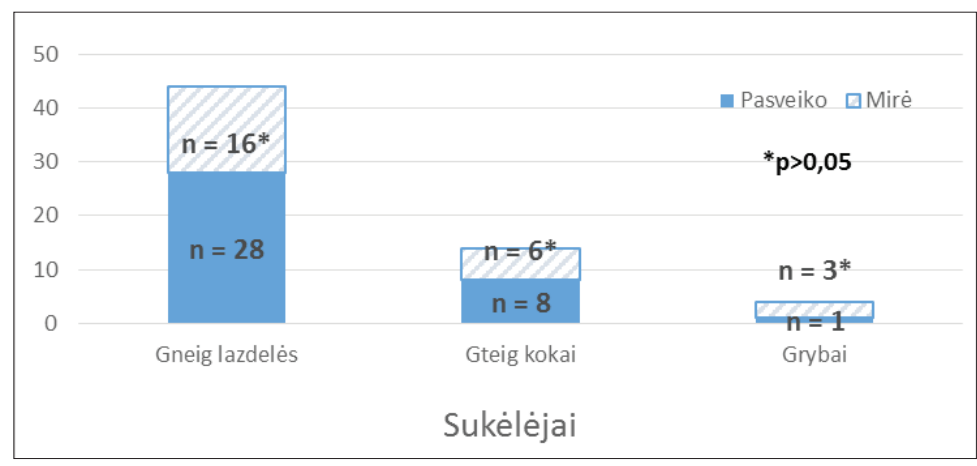

4 pav. Šlapimo organų infekcijų KITS gydymo baigtys pagal sukèlèjus adekvatus, $15,7 \pm 3,3$ d. kai neadekvatus. Šis gydymo trukmès skirtumas buvo statistiškai reikšmingas $(p<0,05)$.

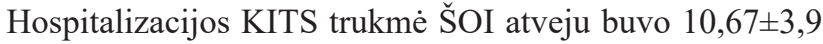
d., kolonizacijos atveju 3,6 $\pm 1,8 \mathrm{~d}$., o tiriamuoju laikotarpiu vidutinè hospitalizacijos KITS trukmè buvo 1,08 $\pm 0,4$ d. ŠOI ar kolonizacijos atveju pacientų hospitalizacijos trukmè KITS buvo statistiškai patikimai ilgesnè $(p<0,05)$. Hospitalizacijos KITS trukmè, kai ŠOI sukèlè grybas buvo $27,75 \pm 12,3$ d., kai bakterijos - 10,68 $\pm 5,3$ d., ir šis skirtumas statistiškai reikšmingas, $p<0,05$. Hospitalizacijos trukmè KITS Gneig lazdeliu ir Gteig kokų sukeltos ŠOI atveju reikšmingai nesiskyrè (buvo atitinkamai 7,55 $\pm 4,4$ d. ir $15,57 \pm 6,7$ d., $p=0,1$ ). Hospitalizacijos KITS trukmè E. coli sukeltos ŠOI atveju 4,2 $\pm 1,7$ d., kitų Gneig lazdelių $10 \pm 5,5 \mathrm{~d}$. ir skyrèsi reikšmingai, $\mathrm{p}<0,05$. Hospitalizacijos KITS trukmé, kai ŠOI sukèlè vienas mikroorganizmas buvo $8,9 \pm 4,1 \mathrm{~d}$, kai keli - 15,4 $\pm 6,4 \mathrm{~d}$., gydymo trukmè šiais atvejais skyrèsi nereikšmingai ( $p>0,05)$. Hospitalizacijos KITS trukme 3,3 $\pm 2,1$ d., kai empirinis antibakterinis gydy-

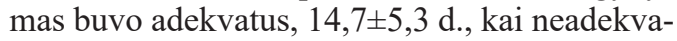
tus, šis hospitalizacijos trukmès skirtumas buvo statistiškai reikšmingas $(\mathrm{p}<0,05)$.

Esant ŠOI, 40 proc. $(\mathrm{n}=21)$ KITS gydytu tirtu pacientu miré, o kolonizacijos atveju visi pacientai išgyveno, šis skirtumas statistiškai reikšmingas $(p<0,05)$. Mirštamumas su lytimi nesusijęs: vyrų mirè $\mathrm{n}=9$, moterų $\mathrm{n}=12$, $\mathrm{p}>0,05$. Pagal amžiaus grupes $>65 \mathrm{~m}$. miré 39,5 proc. ( $\mathrm{n}=17$ is 43$), 50-64 \mathrm{~m}$. - 44proc. $(\mathrm{n}=4$ iš 9), o $18-49 \mathrm{~m}$. išgyveno visi 5 pacientai. Nustatytas reikšmingas skirtumas lyginant abi vyresniujuc grupes su jauniausiais tirtais pacientais, $\mathrm{p}<0,05$. Nenustatėme reikšmingos priklausomybès tarp pacientų mirštamumo ir ŠOI sukèlèjo: jei ŠOI sukèlëjas buvo Gneig lazdelès, mire 16 (36 proc.), jei Gteig kokai - 6 (43 proc.), jei grybai -3 ( 75 proc.) pacientai (4 pav.). Mire 5 iš 11 (45,5 proc.) CD ir ŠOI sirgę KITS gydyti pacientai. CD 1,3 karto didino riziką numirti, sergant ŠOI (95 proc., ŠS 1,3 , PI $0,33-4,99, \mathrm{p}<0,05$ ). Kateterizacijos atveju mirè $n=21$ (42,3 proc.) pacientu ir daugiau nei trys ketvirtadaliai - 76,5 proc. $(\mathrm{n}=13$ iš 17$)$, kuriems taikyta IK. Abiem atvejais gautas statistiškai reikšmingas skirtumas, nes nemirè nẻ vienas pacientas, sirgęs ŠOI be kateterizacijos $(n=7), p<0,05$.

\section{Diskusija}

ŠOI išlieka problema medicinos praktikoje, ypač intensyvios terapijos skyriuose, nepaisant 
to, jog pastaraisiais dešimtmečiais buvo sukurta daug priemonių ir metodikų, siekiant mažinti šių infekcijų dažnį (1, 2). Literatūros duomenimis, pasaulyje tarp dažniausių hospitalinių infekcijų ŠOI tenka pirma ar antra vieta, dažniau nurodomos kvejpavimo takų infekcijos $(5,7)$. ŠOI paplitimas intensyvios terapijos skyriuose, taip pat ir kardiologinio profilio, skirtingų šalių duomenimis, yra nuo $2-10$ proc. išsivysčiusiose valstybèse, iki 20 - 40 proc. besivystančiose (8-16). Lietuvoje intensyvios terapijos skyriuose ŠOI sudaro 3,2 proc. $(17,18)$, o Kauno klinikų ITS - apie 3 proc. (1). Mūsų atliktame tyrime ŠOI dažnis KITS nustatytas tik 0,34 proc. galètų būti dèl didelès pacientų kaitos, trumpos gydymo trukmès ir palankios skyriaus epidemiologinès situacijos.

Kauno klinikų KITS gydytų pacientų bakteriurijos dažnis nepriklausè nuo tiriamujjų lyties. Ji buvo dažnesnè vyresniems pacientams. Tai atitinka kitų autorių duomenis $(3,19)$.

Šlapimo pūslès kateterizacija 80 proc. atvejų sukelia ŠOI, kiekviena diena su šlapimo pūslès kateteriu didina šlapimo organų kolonizacijos mikroorganizmais tikimybę 2-6 proc., o labai sunkių būklių pacientams, sergantiems CD - iki 10 proc $(2,20)$. Vidutinè tirtų KITS pacientų kateterizacijos trukmè 10 d., taigi kiekvieno kateterizuoto paciento rizika mikrobinei kolonizacijai siekè bent 50-60 proc. ar daugiau, todèl beveik visi ( $>90$ proc.) kateterizuotieji turejjo riziką sirgti ŠOI. Taigi, CD ir šlapimo pūslès kateterizacija nustatyti kaip S̆OI rizikos veiksniai atitiko ir kitų autorių nuomonę $(21,22)$.

Literatūros duomenimis, daugiausiai ITS uroinfekcijų sukelia vienas sukèlejas, likusius 5-12 proc. - du $(2,5)$, tai yra kiek mažiau nei KITS. Kritinių būklių pacientams ŠOI dažniausiai sukelia enterobakterijos ir kitos Gneig lazdelès (50-60 proc.), taip pat enterokokai (15-20 proc.) bei grybai (apie 20 proc.) $(2,23)$. Mūsų tyrime taip pat dažniausiai (69 proc.) ŠOI sukèlè Gneig lazdelès (E. coli, Pseudomona, Klebsiella), Gteig kokai (enterokokai) dažniu visiškai atitiko bendrają Lietuvos statistiką, o grybai (Candida) nustatyti triskart rečiau - mažiau nei vieną iš dešimties atvejų. Nors mūsų gauti rezultatai panašūs ị kitų autorių duomenis, kaip ir i bendrają Lietuvos ITS epidemiologinę situaciją $(10-12,18,24)$, visgi dažniau tarp KITS pacientuc ŠOI sukèlëjų tikètina gramneigiama lazdelè. Tai galètų būti siejama ir su šlapimo pasèlio ėmimo dažniu, technika bei laikymo iki ištyrimo sąlygomis, be to, paciento higienos poreikių užtikrinimu. Retesné grybinė ŠOI kilmė nurodytų ị mažesnį kardiologinio profilio pacientų polinkị imunosupresijai.

Dažniausiai empiriškai skirta antibiotiko cefuroksimo (trys ketvirtadaliai ŠOI grupeje), ir tai vertinama kaip adekvatus pasirinkimas vyraujant Gneig lazdelių sukeltai ŠOI. Literatūros duomenimis, prieš skiriant antibakterinị gydymą, svarbiausia atsižvelgti ị skyriaus individualią epidemiologinę situaciją, paciento rizikos veiksnius, ankstesnị antibakterini gydymą bei tikètiną rezistentišku sukèlèjų galimybę (25). Mūsų tyrimo duomenys ir suteikia gydytojui galimybę racionaliai parinkti individualiai adekvatų empirini antimikrobini gydymą pagal aktualią epidemiologinę KITS padèti. Jei paciento būklè nèra sunki ir nèra rezistentiškų sukèlèjų rizikos, ŠOI gydymui tinka skirti antros kartos cefalosporino (cefuroksimo) ar fluorchinolono, o kritinių būklių pacientams, taip pat esant didelei rezistentiškos floros tikimybei empirinei antibiotikoterapijai vertetų rinktis betalaktaminį antibiotiką su betalaktamazių inhibitoriumi (ampiciliną su sulbaktamu, amoksiciliną su klavulanine rūgštimi, piperaciliną su tazobaktamu, cefoperazoną su sulbaktamu) arba karbapenemus (meropenemą, imipenemą ar ertapenemą), o esant Gteig floros rizikai vankomiciną $(24,26)$.

Šio tyrimo metu nustatème, jog kiek mažiau nei pusei sirgusiujų ŠOI empirinis antibakterinis gydymas buvo adekvatus, tuomet nustatyta ir trumpesné ŠOI gydymo trukmé, lyginant su pacientų grupe, kuriems empirinè antibiotikoterapija buvo neadekvati. Tai dar kartą ịrodo adekvataus empirinio antibakterinio gydymo praktinę vertę. Dažniausiai gydymas neadekvatus buvo dèl vieno ar abiejų sukẻlèjų atsparumo cefuroksimui (P. aeruginosa, Klebsiella spp., enterokokų), taip pat jų derinių su retesniais ko-patogenais (Corynebacterium, Citrobacter). P. aeruginosa šioje grupèje buvo jautri ceftazidimui, amikacinui, karbapenemams, Klebsiella spp. - piperacilinui-tazobaktamui, karbapenemams, o enterokokai ir Corynebacterium - vankomicinui, ir tai atitiko kitų šalių duomenis $(24,25)$. Pagal patikslintus sukèlèjų duomenis svarbu kuo skubiau modifikuoti gydymą, keičiant ar pridedant reikiamą $\mathrm{AB}$, plečiant ar atvirkščiai - siaurinant antimikrobinị veikimą. Dažniausias sukèlejjas - E. coli - tik 2 pacientams buvo atsparus cefuroksimui, todèl galima daryti prielaidą, kad 2007-2011 $\mathrm{m}$. KITS išplèstinio spektro betalaktamazes gaminančių E. coli beveik nepasitaikè, nors pasaulyje jos dažnis kai kur siekia net 30 proc. $(9,24,25,27)$.

Adekvati empiriné antibiotikoterapija KITS pacientams ženkliai (beveik 5 kartus) trumpino gydymo trukmę. Trumpiau gydyti tie pacientai, kuriems ŠOI sukèlè E. coli, nes būtent šio sukèlèjo ŠOI atveju empirinis gydymas dažniau buvo adekvatus. Labai sunkių būklių, mechaniškai ventiliuotiems pacientams ŠOI dažniau sukeldavo šiaip jau menkesnio virulentiškumo mikroorganizmas - enterokokas. Šių pacientų gydymo trukmè 5-6 kartus ilgesnè nei pacientų su E. coli sukelta ŠOI, todèl šlapime išaugintą E. coli KITS 
galime laikyti reliatyviai palankesniu prognostiniu veiksniu, sergant ŠOI. Enterokokų sukelta ŠOI minètam pacientų kontingentui nurodo ị didesni jų pažeidžiamumą infekcijos atžvilgiu, be to, šie Gteig kokai dažniau ŠOI sukelia veikdami sinergizme: jie dažniau išauginti kartu su kitu sukèleju, taip pat kitų lokalizacijų hospitaline infekcija jau sergantiems pacientams. Tai galèjo turèti itakos ir ilgesnei šios pacientu grupès hospitalizavimo trukmei. Candida spp. grybo sukeltos ŠOI dažniau pasireiškè kritinès būklès, didelès gydymo ITS trukmès, mechaniškai ventiliuotiems, kateterizuotiems, ilgai gydytiems įvairiais antibakteriniais vaistais pacientams, kaip nurodoma ir kituose šaltiniuose $(28,30,31)$. Grybo sukeltos ŠOI gydymo trukmè galèjo būti ilgiausia, nes priešgrybinis gydymas neskirtas.

KITS pacientų mirštamumas sergant ŠOI siekia apie 40 proc., kitų šalių ITS jis svyruoja nuo 20 iki 50 proc. (32, 33). CD mūsų tyrime nustatytas kaip akivaizdus mirštamumo rizikos veiksnys kritinių būklių pacientams sergant ŠOI, atitinkantis ir kitų autorių duomenis $(15,34)$. Ilgalaikẻ šlapimo pūslès kateterizacija kritinių būklių pacientams labai didina urosepsio ir septicemijos išsivystymo riziką, o tokios būklès pacientų mirštamumą didina tiek mūsų, tiek ir kitų autorių duomenimis $(35,36)$. Esant neadekvačiam empiriniam ŠOI gydymui mirè ne visi pacientai: ketvirtadaliui antimikrobinis gydymas pakeistas ar kombinuotas su adekvačiu antibiotiku. Olandų autoriai nurodo, kad būtina pagal naujausias rekomendacijas modifikuoti antimikrobinị gydymą, jei per $5 \mathrm{~d}$. nestebima teigiamo klinikinio efekto, taip gerinant pacientų išeitis (37), tačiau mirštamumo palyginimui po gydymo modifikavimo duomenų mokslinèje literatūroje stinga.

Šis tyrimas turi kelis ribotumus. Pirmiausia, retrospektyvinio tyrimo pobūdis. Nepaisant to, kad toks tyrimo dizainas nèra pats informatyviausias, tyrimo pobūdis yra praktiškas, ieškant galimų rizikos veiksnių retų patologijų atvejais, kaip mūsų atveju. Antra, mes netyrème gydymo adekvatumo pagal tai, ar bakteriurija (ŠOI) buvo hospitalinès ar visuomeninès kilmès, ar buvo komplikuotos ar nekomplikuotos ŠOI atvejai. Nors ir kitų rizikos veiksnių analizė galètų pateikti papildomų duomenų apie empirinès antibiotikoterapijos adekvatumą ir leistų pateikti daugiau išvadų dẻl racionalaus empirinio antibiotikų skyrimo proporcijų, esama duomenų analizè yra pakankamai reprezentatyvi kasdieninei situacijai, kuomet pakankama informacija apie galimo sukèlèjo pobūdị, ŠOI komplikuotumą ir kitus veiksnius yra labai ribota. Trečia, mūsų statistinè duomenų analizė nèra daugiapakopè. Nors daugiapakopè statistinè duomenų analizè būtų informatyvesnè įrodant rizikos veiksnių reikšmes, mūsų atveju kẻlème tikslą ịvertinti, ar pasaulyje žinomi rizikos veiksniai yra aktualūs Lietuvos tretinio lygio ligoninėje, ar ne. Mūsų tyrime mes patvirtinome, kad Lietuvoje jie yra aktualūs, ir todèl būtina rasti organizacinių ir finansinių galimybių iggyvendinti tarptautines rekomendacijas savalaikiai diagnozuojant ir racionaliai parenkant empirinę antibiotikoterapiją.

\section{Rekomendacijos}

Šlapimo pūslès kateterius naudoti tik esant būtinoms indikacijoms: šokas, didelès apimties ir ilgos trukmès operacija, sunki pilvo ir inkstų trauma, o juos laikyti kiek imanoma trumpiau. Ūminio inkstų pažeidimo atveju taikyti epizodinę, o ne nuolatinę kateterizaciją. Kateterizavus šlapimo pūslę, būtina stebėsena dèl šlapimo organų infekcijos. Atsiradus pirmiesiems jos požymiams, kuo greičiau skirti adekvačią empirinę antibiotikoterapiją. Mūsų tyrimo duomenys ir suteikè KITS gydytojui galimybę racionaliai individualiai parinkti adekvatų empirinị antimikrobinị gydymą. Grybinès kilmès infekcijos atveju būtina skirti priešgrybini gydymą. Neadekvataus empirinio antimikrobinio gydymo atveju ji modifikuoti, taip ženkliai trumpinant gydymo trukmę, hospitalizacijos KITS trukmę bei gerinant pacientų baigtis. Atsižvelgti i CD sergančiuosius: jie pasižymi padidinta sergamumo ŠOI ir mirštamumo nuo jos rizika, todèl šių ligonių hospitalinei priežiūrai turi būti sudaromos būtinosios tinkamos hospitalinę priežiūrą ir racionalų vaistų vartojimą užtikrinančios praktinès sąlygos.

\section{Išvados}

Bakteriurija dažnesnè $>65 \mathrm{~m}$. amžiaus pacientams. Beveik visuomet bakteriurija susijusi su šlapimo organų infekcija, jos reikšmingi rizikos veiksniai - cukrinis diabetas ir šlapimo pūslès kateterizacija. Du trečdaliai šlapimo organų infekcijos sukèlèjų - gramneigiamos lazdelès, iš jų pusė - E. coli. Dažniausiai empiriškai šlapimo organų infekcija gydyta intraveniniu cefuroksimu. Empirinis antibakterinis gydymas adekvatus buvo mažiau nei pusei atvejų, dažniausia gydymo neadekvatumo priežastis - sukèlejo atsparumas skirtam antibiotikui. Tiek šlapimo organu infekcija, tiek ir ju kolonizacija mikrobais didino hospitalizacijos Kardiologijos intensyvios terapijos skyriuje trukmę. Hospitalizacijos Kardiologijos intensyvios terapijos skyriuje trukmé mažesnè, kai šlapimo organų infekcijos sukèlëjas E. coli, didžiausia, kai grybas. Adekvataus antibakterinio gydymo atveju tiek šlapimo organų infekcijos gydymo trukmé, tiek ir bendra hospitalizacijos Kardiologijos intensyvios terapijos skyriuje trukmė ženkliai mažesnè. Kardiologijos intensyvios terapijos skyriaus pacientų, sergančių šlapimo organų infekcija, mirštamumas 40 procentų. Jị didino vyresnis nei $50 \mathrm{~m}$. amžius, cukrinis diabetas bei šlapimo pūslès kateterizacija, ypač - ilgalaikè. 


\section{Literatūra}

1. Adukauskienė D., Kinderytė A., Tarasevičius R., Vitkauskienė A. Uroinfekcijos etiologija, rizikos veiksniai ir baigtis. Medicina (Kaunas), 2006;42(10):805-09.

2. Lopez MJ, Cortez JA. Urinary tract colonization and infection in critically ill patients. Med Intensiva 2012;36(2):143-51. http://dx.doi.org/10.1016/j.medine.2011.06.003

3. Al-Qas Hanna F, Sambirska O, Iyer S, Szpunar S, Fakih MG. Clinician practice and the National Healthcare Safety Network definition for the diagnosis of catheter-associated urinary tract infection. Am J Infect Control 2013;13:973-5. http://dx.doi.org/10.1016/j.ajic.2013.05.024

4. Al-Tawfiq JA, Amalraj A, Memish ZA. Reduction and surveillance of device-associated infections in adult intensive care units at a Saudi Arabian hospital, 2004-2011. Int J Infect Dis 2013;13:228-32.

http://dx.doi.org/10.1016/j.ijid.2013.06.015

5. Vincent JL, Rello J, Marshall J. et al. International study of the prevalence and outcomes of infection in intensive care units. JAMA 2009;302:2323-9.

http://dx.doi.org/10.1001/jama.2009.1754

6. Segagni Lusignani L, Blacky A, Starzengruber P, Diab-Elschahawi M, Wrba T, Presterl E. A national point prevalence study on healthcare-associated infections and antimicrobial use in Austria. Wien Klin Wochenschr 2016;10:1-6 http://dx.doi.org/10.1007/s00508-015-0947-8

7. Hu B, Tao L, Rosenthal VD, Liu K, Yun Y, Suo Y, Gao X, Li R, Su D, Wang H, Hao C, Pan W, Saunders CL. Device-associated infection rates, device use, length of stay, and mortality in intensive care units of 4 Chinese hospitals: International Nosocomial Control Consortium findings. Am J Infect Control 2013;41(4):301-6.

http://dx.doi.org/10.1016/j.ajic.2012.03.037

8. El-Kholy A, Saied T, Gaber M, Younan MA, Haleim MM, ElSayed H, El-Karaksy H, Bazara'a H, Talaat M. Device-associated nosocomial infection rates in intensive care units at Cairo University hospitals: first step toward initiating surveillance programs in a resource-limited country. Am J Infect Control 2012;40(6):216-20.

http://dx.doi.org/10.1016/j.ajic.2011.12.010

9. Joon Ho Lee, Sun Wook Kim, Byung Il Yoon, U-Syn Ha, Dong Wan Sohn and Yong-Hyun Cho. Factors that affect nosocomial catheter-associated urinary tract infection in intensive care units: 2-Year Experience at a Single Center. Korean J Urol 2013;54(1):59-65.

http://dx.doi.org/10.4111/kju.2013.54.1.59

10. Edwards JR, Peterson KD, Mu Y, Banerjee S, Allen-Bridson, K, Morrell G. et al. National Healthcare Safety Network (NHSN) report: data summary for 2006 through 2008, issued December 2009. Am J Infect Control 2009;37:783-805.

http://dx.doi.org/10.1016/j.ajic.2009.10.001

11. Agodi A, Auxilia F, Barchitta M, Brusaferro S, D'Alessandro,
D, Montagna MT. et al. Building a benchmark through active surveillance of intensive care unit-acquired infections: the Italian network SPIN-UTI. J Hosp Infect 2010;74:258-65.

http://dx.doi.org/10.1016/j.jhin.2009.08.015

12. Tay MK, Lee JY, Wee IY, Oh HM. Evaluation of intensive care unit-acquired urinary tract infections in Singapore. Ann Acad Med Singapore 2010;39(6):460-5.

13. Simonetti A, Ottaiano E, Diana MV, Onza C, Triassi M. Epidemiology of hospital-acquired infections in an adult intensive care unit: results of a prospective cohort study. Ann Ig 2013;25(4):281-9.

14. Ak O, Batirel A, Ozer S, Çolakoğlu S. Nosocomial infections and risk factors in the intensive care unit of a teaching and research hospital: a prospective cohort study. Med Sci Monit 2011;17(5):29-34.

http://dx.doi.org/10.12659/MSM.881750

15. Gillen JR, Isbell JM, Michaels AD, Lau CL, Sawyer RG. Risk factors for urinary tract infections in cardiac surgical patients. Surg Infect 2015;16(5):504-8.

http://dx.doi.org/10.1089/sur.2013.115

16. Álvarez Lerma F, Carrasco M, Otal JJ, Palomar M, Olaechea P, Peris X, Iglesias L, Martínez Pellus A, Arenzana A, Ballesteros JC; Grupo de Estudio ENVIN-HELICS. Invasive device-related infections after heart surgery. Med Intensiva 2013;37(9):58492.

http://dx.doi.org/10.1016/j.medine.2012.12.008

17. Valinteliene R, Gailiene G, Berzanskyte A. Prevalence of healthcare-associated infections in Lithuania. J Hosp Infect 2012;80(1):25-30.

http://dx.doi.org/10.1016/j.jhin.2011.09.006

18. Lietuvos higienos instituto hospitalinių infekcijų epidemiologinès priežiūros reanimacijos ir intensyvios terapijos skyriuose ataskaitos: 2012m. ataskaita (http://www.hi.lt/images/ RITS_2012-bendra_new.pdf)

19. M.G. Fakih, S.P. Shemes, M.E. Pena, N. Dyc, J.E. Rey, S.M. Szpunar. et al. Urinary catheters in the emergency department: very elderly women are at high risk for unnecessary utilization. Am J Infect Control 2010;38:683-8. http://dx.doi.org/10.1016/j.ajic.2010.04.219

20. Jacobsen SM, Stickler DJ, Mobley HL, Shirtliff ME. Complicated catheter-associated urinary tract infections due to Escherichia coli and Proteus mirabilis. Clin Microbiol Rev 2008;21(1):26-59. http://dx.doi.org/10.1128/CMR.00019-07

21. Van der Kooi TI, de Boer AS, Mannien J, Wille JC, Beaumont MT,Mooi BW, et al. Incidence and risk factors of device-associated infections and associated mortality at the intensive care in the Dutch Surveillance System. Intensive Care Med 2007;33:271-8.

http://dx.doi.org/10.1007/s00134-006-0464-3

22. Mojtahedzadeh M, Panahi Y, Fazeli MR, Najafi A, Pazouki $\mathrm{M}$, Navehsi BM, et al. Intensive care unit-acquired urinary 
tract infections in patients admitted with sepsis: etiology, risk factors, and patterns of antimicrobial resistance. Int $\mathrm{J}$ Infect Dis 2008;12:312-8.

http://dx.doi.org/10.1016/j.ijid.2007.09.005

23. Olaechea PM, Insausti J, Blanco A, Luque P. Epidemiology and impact of nosocomial infections. Med Intensiva 2010;34:256-67.

http://dx.doi.org/10.1016/j.medin.2009.11.013

24. Lu PL, Liu YC, Toh HS, Lee YL, Liu YM, Ho CM, Huang CC, Liu CE, Ko WC, Wang JH, Tang HJ, Yu KW, Chen YS, Chuang YC, Xu Y, Ni Y, Chen YH, Hsueh PR. Epidemiology and antimicrobial susceptibility profiles of Gram-negative bacteria causing urinary tract infections in the Asia-Pacific region: 2009-2010 results from the Study for Monitoring Antimicrobial Resistance Trends (SMART). Int J Antimicrob Agents 2012;40:37-43.

http://dx.doi.org/10.1016/S0924-8579(12)70008-0

25. Zilberberg MD, Shorr AF. Secular trends in gram-negative resistance among urinary tract infection hospitalizations in the United States, 2000-2009. Infect Control Hosp Epidemiol 2013;34(9):940-6.

http://dx.doi.org/10.1086/671740

26. Hooton TM, Bradley SF, Cardenas DD. et al. Diagnosis, prevention, and treatment of catheter-associated urinary tract infection in adults: 2009 International Clinical Practice Guidelines from the Infectious Diseases Society of America. Clin Infect Dis 2010;50(5):625-63.

http://dx.doi.org/10.1086/650482

27. Tham J, Odenholt I, Walder M, Andersson L, Melander E. Risk factors for infections with extended-spectrum beta-lactamaseproducing Escherichia coli in a county of Southern Sweden. Infect Drug Resist 2013;19(6):93-97.

http://dx.doi.org/10.2147/IDR.S46290

28. Massanet P, Jung B, Molinari N, Villiet M, Moulaire V, RochTorreilles I, Jaber S, Reynes J, Corne P. Antifungal treatment for suspected or proved candidiasis in the critically ill. Ann Fr Anesth Reanim 2014;33(4):232-9.

http://dx.doi.org/10.1016/j.annfar.2014.02.016

29. Kennedy EH, Greene MT, Saint S. Estimating hospital costs of catheter-associated urinary tract infection. J Hosp Med 2013;8(9):519-22.

http://dx.doi.org/10.1002/jhm.2079

30. Yang SP, Chen YY, Hsu HS, Wang FD, Chen LY, Fung CP. A risk factor analysis of healthcare-associated fungal infections in an intensive care unit: a retrospective cohort study. BMC Infect Dis 2013;9(13):10.

http://dx.doi.org/10.1186/1471-2334-13-10

31. Maldonado I, Arechavala A, Guelfand L, Relloso S, Garbasz C; de la Red de Micología de la Ciudad de Buenos Aires. Yeast urinary tract infections. Multicentre study in 14 hospitals belonging to the Buenos Aires City Mycology Network. Rev Iberoam Micol 2016;15:77-7.
32. Chen YY, Chen LY, Lin SY, Chou P, Liao SY, Wang FD. Surveillance on secular trends of incidence and mortality for device-associated infection in the intensive care unit setting at a tertiary medical center in Taiwan, 2000-2008: a retrospective observational study. BMC Infect Dis 2012;12:209.

http://dx.doi.org/10.1186/1471-2334-12-209

33. Pradhan NP, Bhat SM, Ghadage DP. Nosocomial infections in the medical ICU: a retrospective study highlighting their prevalence, microbiological profile and impact on ICU stay and mortality. J Assoc Physicians India 2014;62(10):18-21.

34. Lola I, Levidiotou S, Petrou A, Arnaoutoglou H, Apostolakis E, Papadopoulos GS. Are there independent predisposing factors for postoperative infections following open heart surgery? J Cardiothorac Surg 2011;14(6):151.

http://dx.doi.org/10.1186/1749-8090-6-151

35. Lo, E., L. Nicolle. et al. Strategies to prevent catheter-associated urinary tract infections in acute care hospitals. Infect Control Hosp Epidemiol 2008;29:41-50.

http://dx.doi.org/10.1086/591066

36. Laurie J. Conway, Elaine L. Larson. Guidelines to prevent catheter-associated urinary tract infection: 1980 to 2010. Heart Lung 2012;41(3):271-283.

http://dx.doi.org/10.1016/j.hrtlng.2011.08.001

37. Spoorenberg V, Prins JM, Stobberingh EE, Hulscher ME, Geerlings SE. Adequacy of an evidence-based treatment guideline for complicated urinary tract infections in the Netherlands and the effectiveness of guideline adherence. Eur J Clin Microbiol Infect Dis 2013;32(12):1545-56.

http://dx.doi.org/10.1007/s10096-013-1909-6

\section{URINARY TRACT INFECTION IN CARDIAC INTENSIVE CARE UNIT \\ D. Adukauskienė, T. Kaučikas, A. Adukauskaitė, R. Mačiulaitis, I. Skarupskienė, D. Pentiokinienė, G. Stanaitienè}

Key words: urinary tract infection, risk factors, antimicrobial treatment, mortality.

Summary

Aim of study. Estimation of urinary tract infection (UTI) risk factors, antimicrobial treatment, length of UTI-treatment and stay in Cardiac intensive care unit (CICU), mortality and its risk factors in CICU patients.

Methods. Retrospective analysis of data of 57 patients with bacteriuria, who were treated in Kaunas Clinics CICU.

Results. Bacteriuria rate between males and females was found to be equal (47,4\% and 52,5\%). Mean age 73,01 $\pm 12,3$ y/o; bacteriuria was more often present among patients over 65 $y / o$ compared to younger ones, $p<0,05.52$ out of 57 had UTI. UTI has evolved in all 11 patients with diabetes mellitus (DM). Urinary catheterization was performed in 49 patients, of whom 45 had UTI. Mean urinary catheterization duration was found to be $10 \pm 2$ days. Most often UTI was caused by Gram-negative rods -44 cases out of 64 , among which by E. coli $-43,2 \%(p<0,05)$; fungi were 
found in critical and longer treated patients. The most often used antibiotic (AB) - cefuroxime (77\%). Duration of UTI in patients with adequate empirical antibacterial treatment $(\mathrm{n}=24,46 \%)$ was $9,9 \pm 4,7$ days, in patients with inadequate $\mathrm{AB}$-treatment (usually because of antibacterial resistance) $15,7 \pm 3,3$ days, $p<0,05$. Mean length of stay in CICU in case of colonization was $3,6 \pm 1,8$ days, in case of UTI - 10,67 $\pm 3,9$ days and generally mean length of stay in CICU was found to be $1,08 \pm 0,4$ days, $p<0,05$. When UTI was caused by fungi, length of stay in CICU was $27,75 \pm 12,3$ days, when caused by bacteria $-10,68 \pm 5,3$ days, $p<0,05$. When empirical antibacterial treatment was adequate, duration of treatment in $\mathrm{CICU}$ was $3,3 \pm 2,1$ days, when inadequate $-14,7 \pm 5,3$ days, $\mathrm{p}<0,05$. Mortality was related to age over $50 \mathrm{y} / \mathrm{o}, \operatorname{DM}(95 \%$, OR $1,3, \mathrm{CI} 0,33$ $-4,99$ ), urinary tract catheterization and its duration (all patients were catheterized; among those with long term catheterization 76 $\%$ died), $\mathrm{p}<0,05$.

Conclusions. Bacteriuria is prevalent among patients over 65 $\mathrm{y} / \mathrm{o}$ and is almost always related to UTI, which has relevant risk factors, such as DM and urinary catheterization. Two thirds of UTI causal agents are Gram-negative rods, in half of cases - E. coli. Most often empirical antibiotic was intravenous cefuroxime. Empirical antibiotic treatment was adequate in half of the cases; the most often cause of inadequacy was antimicrobial resistance. Length of stay in CICU was longer not only in case of UTI, but in case of urinary colonization as well. Length of stay in CICU was shortest when UTI was caused by E. coli and longest when caused by fungi. In case of adequate antibacterial treatment, the length of UTI-treatment as well as stay in CICU is significantly shorter. Mortality of CICU patients with UTI is $40 \%$. The mortality rate was related to age over $50 \mathrm{y} / \mathrm{o}$, DM and urinary catheterization, especially, long term.

Correspondence to: tadas.kaucikas@gmail.com

Gauta 2016-04-06 